\title{
Lost in Transition
}




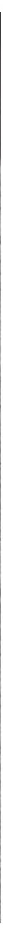




\section{Lost in Iransition}

ETHNOGRAPHIES

OF EVERYDAY LIFE

AFTER COMMUNISM

\section{Kristen Ghodsee}

Duke University Press Durham and London 2011 
(C) 2011 Duke University Press

All rights reserved

Printed in the United States of America on acid-free paper $\infty$

Designed by Heather Hensley

Typeset in Whitman by Keystone Typesetting, Inc.

Library of Congress Cataloging-in-Publication Data appear on the last printed page of this book. 
